International Journal of Social Science And Human Research

ISSN(print): 2644-0679, ISSN(online): 2644-0695

Volume 03 Issue 12 December 2020

DOI: $10.47191 / \mathrm{ijsshr} / \mathrm{v} 3-\mathrm{i} 12-03$

Page No : 377-385

\title{
Gender Differences in the Use of Social Media: Australian Postgraduate Students' Evidence
}

\author{
Ashkan Mirzay Fashami \\ Griffith Business School, Griffith University, Brisbane, Queensland, Australia
}

\begin{abstract}
This study investigates the differences between male and female usage of social media in Australia. The sample consists of ten postgraduate students at the Queensland University of Technology who use social media platforms, including six males and four females.Nine themes and 41 codes are identified. This study analyses five major themes, namely, personal life, professional life, sharing, leaders or followers, and competition. Six participants consider themselves as either leaders or followers in their social media usage, making this theme the most acknowledged theme. However, three participants use social media for their personal lives, and social media challenge three participants. Therefore, personal life and competition are the least important cause of social media usage. This study contributes by shedding some light on social media usage among postgraduate students. It helps universities to choose among different social media platforms for their educational purposes for their postgraduate students.

Keywords: Australia, Female, Gender, Male, Postgraduate Student, Social Media.
\end{abstract}

\section{INTRODUCTION}

This study investigates the differences between male and female usage of social media in Australia. Social media are web-based tools that enable their users to communicate with each other and exchange resources (Gould, 2013) ${ }^{[1]}$, which currently play an important role across many aspects of life (Kietzmann, Hermkens, 2011) ${ }^{[2,}$ Manzoor and Khan, 2019) ${ }^{[3]}$. They reinforce the sense of belonging and reduce the distance among people (Almenara-Niebla and Ascanio-Sánchez, 2020) ${ }^{[4]}$.People share their personal experiences on social media platforms such as Facebook(Almenara-Niebla and Ascanio-Sánchez, 2020) ${ }^{[4]}$. Nearly two billion people have used social media as of 2014, of which Facebook has the highest number of active users (Statista, 2014) ${ }^{[5]}$.Though various studies suggest the effects of gender differenceson social media usage there is not a clear understanding ofhow males and females differ in their social media usage (Kwon and Wen, 2010) ${ }^{[6]}$.This research aims to fill this gap byanswering the research question of how do males and females differ in their use of social media in Australia?

Prior evidence suggests a relationship between gender and linguistic choices (Bamman, Eisenstein, 2014) ${ }^{[7,}$ Herring and Paolillo, 2006) ${ }^{[8]}$. For example, males and females prefer informational and interaction words, accordingly (Herring and Paolillo, 2006) ${ }^{[8]}$. Males prefer formal and explicit, whereas females prefer deictic and contextual language (Heylighen and Dewaele, 2002) ${ }^{[9]}$.Males use more content-related, while females use more style-related factors (Argamon, Koppel, 2003) ${ }^{[10]}$. Males and females are more likely to write filter and diary blogs, accordingly (Herring and Paolillo, 2006) ${ }^{[8]}$. Males tweet affirmations like yeah and yea, however, females tweet more emoticons, ellipses (...), expressive lengthening (nooowaaay), complex punctuation (!! and ?!), and transcriptions of backchannels (ah, hmm) (Rao, Yarowsky, 2010) ${ }^{[11]}$.Males use the term dude to satisfy their desire for homosocial solidarity without compromising their heterosexuality (Kiesling, 2004) ${ }^{[12]}$.

This study is motivated by prior research failure to analyze male and female differences in their use of social media among Australian postgraduate students. For example, Evers, Albury (2013) ${ }^{[13]}$ investigated the use of social media among young Australians (16 to 22 years old).Wright and Rubin (2017) ${ }^{[14]}$ assessed the relationship between sexual contents in social media and risk among Australian undergraduate students. This study contributes by shedding some light on social media usage among postgraduate students. It helps universities to choose among different social media platforms for their educational purposes for their postgraduate students. Moreover, it shows how males and females treat the information in different platforms, facilitating universities' planning.

The rest of this paper is organized as follows: Section 2 reviews past studies, Section 3 describes this study's methodology, Section 4 reports and discusses the findings, and Section 5 provides a conclusion.

\section{LITERATURE REVIEW}

Social media are "a group of Internet-based applications that build on the ideological and technological foundations of Web 2.0, and that allow the creation and exchange of User Generated Content" (Kaplan and Haenlein, 2010, p. 60) ${ }^{[15]}$. Social media can 


\section{Gender Differences in the Use of Social Media: Australian Postgraduate Students' Evidence}

have various applications such as collaborative projects, blogs, content communities, social networking sites, virtual game worlds, and virtual social worlds (Kaplan and Haenlein, 2010) ${ }^{[15]}$. Different applications enable communications, information sharing, and collaboration (Anttiroiko and Savolainen, 2011) ${ }^{[16]}$. Social media are used for different purposes. For example, they help to track disease rates (Paul and Dredze, 2011) ${ }^{[17]}$, psychological well-being (De Choudhury, Counts, 2013) ${ }^{[18]}$, and other behavioral, psychological, and medical phenomena (Kosinski, Stillwell, 2013) ${ }^{[19]}$.Moreover, they areused to imply demographic attributes such as native language (Argamon, Koppel, 2009) ${ }^{[20]}$, origin (Rao, Yarowsky, 2010) ${ }^{[11]}$, and location (Jones, Kumar, 2007) ${ }^{[21]}$. Furthermore, they are used for educational purposes (Pal and Misra, 2019) ${ }^{[22]}$. Chatting and messaging are common among social media users (Gross, 2004) ${ }^{[23,}$ Vasan, 2016) ${ }^{[24]}$.

Social media such as Facebook can improve people's psychological wellbeing (Grieve, Indian, 2013) ${ }^{[25]}$. People use social media to maintain long-term relationships and support their friends (Anderson, Fagan, 2012) ${ }^{[26]}$. Facebook and Twitter are commonly used social media platforms because they have user profiles, permit to make friends (or follow on Twitter), and include social networks that enable users to meet friends of friends (Boyd and Ellison, 2007) ${ }^{\text {[27] }}$. People use Facebook to communicate work-related matters to their friends rather than to conduct any work (Madge, Meek, 2009) ${ }^{\text {[28] }}$. For example, students use Facebook to share news regarding their assignments rather than to complete the assignment.People use Facebook to receive personal information and view relationships among different users (Karakayali and Kilic, 2013) ${ }^{[29]}$.Facebook profiles can reveal an individual's personality (Back, Stopfer, 2010) ${ }^{[30]}$. Moreover, the type of shared information provides a good picture of the individual's personality (Matzler, Renzl, 2008) ${ }^{[31]}$.

A profile picture is an important part of a social platform (Zheng, Yuan, 2016) ${ }^{[32]}$.The picture can provide important

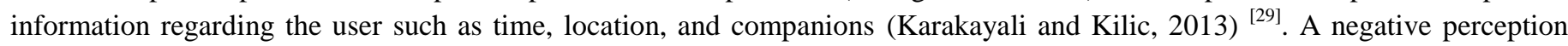
regarding the profile picture can affect the user's well-being. Gender can affect the choice of the profile picture.For example, females are more likely to choose attractive profile pictures (Kapidzic and Herring, 2015) ${ }^{\text {[33] }}$. A profile picture's attractiveness affects the likelihood of being befriended with females attracting greater attention than males (Seidman and Miller, 2013) ${ }^{[34]}$.Moreover, gender differences exist in online image-based self-presentations (Yang and Li, 2014) ${ }^{[35]}$ and affect stereotyping on selfies(Döring, Reif, 2016) ${ }^{[36]}$.

Social media platforms such as Twitter are important parts of Personal Learning Environments (Reed, 2013) ${ }^{[37]}$ and empower people's networking(Simoes and Mota, 2010) ${ }^{[38]}$ to gain knowledge (Couros, 2010) ${ }^{[39]}$.Twitter is used in higher education for recruitment, marketing, and social communication (Palmer, 2013) ${ }^{[40]}$. It can extend teaching practices beyond their formal means (Evans, 2014) ${ }^{[41]}$. Twitter is used to enhance learning through opinion and content exchange (Conole and Alevizou, 2010) ${ }^{[42]}$ and activities such as storytelling (Fernández Sánchez, Revuelta Domínguez, 2012) ${ }^{[43]}$. Its hashtags are used for class discussions and debates (McArthur and Bostedo-Conway, 2012) ${ }^{[44]}$.Backchannels which refer to using Twitter to enhance interaction in face-to-face lessons are used for learning purposes (Kwak, Lee, 2010) ${ }^{[45]}$. Research suggests positive outcomes regarding Twitter and students' learning (Carpenter and Krutka, 2014) ${ }^{[46,}$ Badge, Johnson, 2012) ${ }^{[47,}$ Rinaldo, Tapp, 2011) ${ }^{[48]}$. Students have a positive perception regarding the relationship between Twitter and their learning (McArthur and BostedoConway, 2012) ${ }^{[44]}$ and consider Twitter as a credible source (Johnson, 2011) ${ }^{[49]}$.

Students are active users of different social media platforms (Duggan, Ellison, 2015) ${ }^{[50]}$, using them for academic and non-academic purposes (Kim, Sin, 2014) ${ }^{[51]}$. Social media are used to improve students' engagement in academic activities (Špiranec and Zorica, 2010) ${ }^{[52]}$. For example, some institutions use collaborative environments to enhance their students' learning. Moreover, some libraries through their guidelines and resources guide their students' engagement with different platforms (Witek and Grettano, 2012) ${ }^{[53]}$. Social media affects students' information behavior(Chen, Sin, 2015) ${ }^{[54]}$ because students are not often attentive in their information gathering (Connaway, Dickey, 2011) ${ }^{[55]}$. They usually do not verify the information that they obtain in different social media platforms (Kim, Sin, 2014) ${ }^{[51]}$.Furthermore, they may assess the credibility of a social media platform through imprecise means such as its site's design (Lim and Simon, 2011) ${ }^{[56]}$.

Prior social science research suggests differences between males and females. For example, females live longer than males (Marengoni, Angleman, 2011) ${ }^{[57]}$, their work preferences are different (Su, Rounds, 2009) ${ }^{[58]}$, they use different types of language in social media (Huffaker and Calvert, 2005) ${ }^{[59]}$, females are generally more active in social media (Sap, Park, 2014) ${ }^{[60]}$, and males prefer Twitter (Mislove, Lehmann, 2011) ${ }^{[61]}$.Gender differences are examined across blogs (Goswami, Sarkar, 2009) ${ }^{[62]}$, Yahoo search queries (Jones, Kumar, 2007) ${ }^{[21]}$, and Twitter (Liu and Ruths, 2013) ${ }^{[63]}$.Females are main users of Facebook and online pinboardPinterest, whereas males use music-sharing sites such as last.fm or Reddit which sometimes include misogynistic contents (Women, 2012) ${ }^{[64]}$. Females like to compare their physical attractiveness with online photos (Haferkamp and Krämer, 2011) ${ }^{[65]}$. Moreover, they are more likely to perform reassurance-seeking behaviors(Starr and Davila, 2008) ${ }^{[66]}$.

Males more often upload online videos and use video-sharing applications(Lenhart, Madden, 2007) ${ }^{[67]}$. They are more likely to play video games and visit video websites such as YouTube (Rideout, Foehr, 2010) ${ }^{\text {[68] }}$. However, females prefer to create and share videos and are more likely to video chat (Lenhart, 2012) ${ }^{[69]}$. Males use social platforms to meet new people and make friends (Herring and Kapidzic, 2015) ${ }^{[70]}$ and may join social network sites that are different from their offline peer circles (Barker, 2009) ${ }^{[71]}$. However, females use social platforms to communicate with their friends and strengthen their current 


\section{Gender Differences in the Use of Social Media: Australian Postgraduate Students' Evidence}

relationships (Herring and Kapidzic, 2015) ${ }^{[70]}$. Males and females post different contents to their profiles. Males share selfpromoting contents and sexual pictures, whereas females use cute pictures (Peluchette and Karl, 2008) ${ }^{[72]}$. Gender affects the choice of the profile picture (Zheng, Yuan, 2016) ${ }^{[32]}$.Overall, males and females visit different sites and perform different activities in their visited sites. Therefore, this study investigates the following research question:

How do males and females differ in their use of social media in Australia?

\section{METHODOLOGY}

\section{A. DataCollection}

A qualitative approach helps to thoroughly examineparticipants' experiences in explanatory research through various research methods (Hennink, Hutter, 2010) ${ }^{[73]}$.Therefore, it is chosen for this study to obtain a better understanding of males and females usage of social media(Tracy, 2012) ${ }^{[74]}$. A focus group helps to identifydifferent participants' perspectives. Further, each participant can contribute,by commenting onpoints raised by other participants(Powell and Single, 1996) ${ }^{[75]}$. This study uses a focus group to discoversignificant areas (Morgan, 1997) ${ }^{[76]}$.

\section{B. Sample}

The suitable number of participants in a focus group is between eight to 12 people (Krueger and Casey, 2009) ${ }^{[77]}$. A representative of ten postgraduate studentsat the Queensland University of Technology who use social media platforms, including six males and four females are chosen.Five open-ended questions together with probing questions are asked in an interview of 30 minutes.Notetakersobserve the non-verbal expressions of participants. The session is audio recorded and transcripts are made available for data analysis.The identities of participantsare kept confidential throughout the analysis.Tables 1 to 7 present the demographic characteristics of participants.

Table 1.Age Categories of Participants of this Study

\begin{tabular}{lll}
\hline Age & Male & Female \\
\hline Under 18 & 0 & 0 \\
$18-29$ & 3 & 3 \\
$30-49$ & 3 & 0 \\
$50+$ & 0 & 1 \\
Total & 6 & 4 \\
\hline
\end{tabular}

Table 2. Social Media Usage of Participants of this Study

\begin{tabular}{lll}
\hline Age & Male & Female \\
\hline Facebook & 6 & 3 \\
Instagram & 0 & 1 \\
Twitter & 3 & 0 \\
Pinterest & 0 & 1 \\
LinkedIn & 4 & 3 \\
Google+ & 2 & 3 \\
Myspace & 1 & 0 \\
Tumblr & 1 & 0 \\
WeChat & 1 & 1 \\
\hline
\end{tabular}

Table 3. Frequency of Social Media Usage of Participants of this Study

\begin{tabular}{|c|c|c|c|c|c|c|c|c|c|c|}
\hline & $\begin{array}{l}\text { Many times } \\
\text { per day }\end{array}$ & $\begin{array}{l}\text { Few } \\
\text { times } \\
\text { per day }\end{array}$ & $\begin{array}{l}\text { Once per } \\
\text { day }\end{array}$ & $\begin{array}{l}\text { Few times } \\
\text { per week }\end{array}$ & $\begin{array}{l}\text { Once } \\
\text { week }\end{array}$ & $\mathrm{a}$ & $\begin{array}{l}\text { Few times } \\
\text { per month }\end{array}$ & $\begin{array}{l}\text { Once a } \\
\text { month }\end{array}$ & $\begin{array}{lr}\text { Less than } \\
\text { once a } \\
\text { month }\end{array}$ & Never \\
\hline Facebook & 5 & 2 & 2 & 0 & 0 & & 0 & 0 & 0 & 1 \\
\hline Instagram & 0 & 0 & 1 & 0 & 0 & & 0 & 0 & 1 & 8 \\
\hline Twitter & 0 & 0 & 1 & 0 & 0 & & 1 & 0 & 1 & 7 \\
\hline Pinterest & 0 & 0 & 0 & 1 & 0 & & 0 & 0 & 1 & 8 \\
\hline LinkedIn & 0 & 0 & 2 & 2 & 0 & & 3 & 1 & 0 & 2 \\
\hline Google+ & 1 & 2 & 1 & 0 & 1 & & 0 & 0 & 0 & 5 \\
\hline Myspace & 0 & 0 & 0 & 0 & 1 & & 0 & 0 & 0 & 9 \\
\hline
\end{tabular}


Gender Differences in the Use of Social Media: Australian Postgraduate Students' Evidence

\begin{tabular}{llllllllll}
\hline Tumblr & 0 & 0 & 0 & 0 & 0 & 0 & 1 & 0 & 9 \\
WeChat & 2 & 0 & 0 & 0 & 0 & 0 & 0 & 0 & 8 \\
\hline
\end{tabular}

Table 4.Frequency of Social Media Usage of Male Participants of this Study

\begin{tabular}{llllllllll}
\hline & $\begin{array}{l}\text { Many } \\
\text { times } \\
\text { day }\end{array}$ & $\begin{array}{l}\text { Few times } \\
\text { per day }\end{array}$ & $\begin{array}{l}\text { Once per } \\
\text { day }\end{array}$ & $\begin{array}{l}\text { Few times } \\
\text { per week }\end{array}$ & $\begin{array}{l}\text { Once a } \\
\text { week }\end{array}$ & $\begin{array}{l}\text { Few times } \\
\text { per month }\end{array}$ & $\begin{array}{l}\text { Once a } \\
\text { month }\end{array}$ & $\begin{array}{l}\text { Less than } \\
\text { once a } \\
\text { month }\end{array}$ & Never \\
\hline Facebook & 4 & 1 & 1 & 0 & 0 & 0 & 0 & 0 & 0 \\
Instagram & 0 & 0 & 0 & 0 & 0 & 0 & 0 & 1 & 5 \\
Twitter & 0 & 0 & 1 & 0 & 0 & 1 & 0 & 0 & 4 \\
Pinterest & 0 & 0 & 0 & 0 & 0 & 0 & 0 & 1 & 5 \\
LinkedIn & 0 & 0 & 2 & 0 & 0 & 2 & 1 & 0 & 1 \\
Google+ & 1 & 0 & 0 & 0 & 1 & 0 & 0 & 0 & 4 \\
Myspace & 0 & 0 & 0 & 0 & 1 & 0 & 0 & 0 & 5 \\
Tumblr & 0 & 0 & 0 & 0 & 0 & 0 & 1 & 0 & 5 \\
WeChat & 1 & 0 & 0 & 0 & 0 & 0 & 0 & 0 & 5 \\
\hline
\end{tabular}

Table 5. Frequency of Social Media Usage of Female Participants of this Study

\begin{tabular}{lllllllllll}
\hline & $\begin{array}{l}\text { Many } \\
\text { times } \\
\text { per day }\end{array}$ & $\begin{array}{l}\text { Few times } \\
\text { per day }\end{array}$ & $\begin{array}{l}\text { Once } \\
\text { per day }\end{array}$ & $\begin{array}{l}\text { Few times } \\
\text { per week }\end{array}$ & $\begin{array}{l}\text { Once a } \\
\text { week }\end{array}$ & $\begin{array}{l}\text { Few times } \\
\text { per month }\end{array}$ & $\begin{array}{l}\text { Once a } \\
\text { month }\end{array}$ & $\begin{array}{l}\text { Less than } \\
\text { once } \\
\text { month }\end{array}$ & Never \\
\hline Facebook & 1 & 1 & 1 & 0 & 0 & 0 & 0 & 0 & 1 \\
Instagram & 0 & 0 & 1 & 0 & 0 & 0 & 0 & 0 & 3 \\
Twitter & 0 & 0 & 0 & 0 & 0 & 0 & 0 & 1 & 3 \\
Pinterest & 0 & 0 & 0 & 1 & 0 & 0 & 0 & 0 & 3 \\
LinkedIn & 0 & 0 & 0 & 2 & 0 & 1 & 0 & 0 & 1 \\
Google+ & 0 & 2 & 1 & 0 & 0 & 0 & 0 & 0 & 1 \\
Myspace & 0 & 0 & 0 & 0 & 0 & 0 & 0 & 0 & 4 \\
Tumblr & 0 & 0 & 0 & 0 & 0 & 0 & 0 & 0 & 4 \\
WeChat & 1 & 0 & 0 & 0 & 0 & 0 & 0 & 0 & 3 \\
\hline
\end{tabular}

Table 6. Devices Used by Participants of this Study

\begin{tabular}{lll}
\hline & Male & Female \\
\hline Desktop & 4 & 2 \\
Laptop & 5 & 3 \\
Tablet (IPAD) & 3 & 2 \\
Mobile Phone & 6 & 4 \\
\hline
\end{tabular}

Table 7. Frequency of Devices Used by Participants of this Study

\begin{tabular}{lllllll}
\hline & Frequently & & Occasionally & Never & \\
\hline & Male & Female & Male & Female & Male & Female \\
Desktop & 2 & 0 & 3 & 2 & 1 & 2 \\
Laptop & 1 & 1 & 4 & 2 & 1 & 1 \\
Tablet (IPAD) & 2 & 0 & 1 & 2 & 3 & 2 \\
Mobile Phone & 4 & 2 & 2 & 2 & 0 & 0 \\
\hline
\end{tabular}

\section{Coding}

This study uses open and axial coding for data analysis.Open coding leads to develop concepts, categories, and properties. Moreover, it brings connections between a category and its sub-categories (Pandit, 1996) ${ }^{[78]}$. Axial coding helps to build a theoretical framework through making connections between different categories and theirsub-categories (Corbin and Strauss, 2007) ${ }^{[79]}$.This study identifies nine main themes (higher-level coding) and 41 categories (lower- level coding).Personal life, professional life, sharing, leaders or followers, competition, relationship, geographical distance, lack of desire about social media, and non-verbal expressions while answering are the main themes. 


\section{Gender Differences in the Use of Social Media: Australian Postgraduate Students' Evidence}

\section{RESULTS}

\section{A. Personallife}

Personal lifeis an identified theme,incorporated into two differentcodes.Three participants use social media for their personal lives, making personal reasons the least important cause of social media usage. Males use social media to find a partner because a male participant mentions that "To be very honest when I started using social media it was when I was 15 years old so as a teenager, I wanted to find girlfriends."However, both genders use social media for recreational reasons because it is mentioned by both genders. A male participant mentions that "I like when I go to Facebook when I read a bad comment from other people about one thing... Just feel like crazy when I saw a crazy comment about one thing", and a female participantmentions that "It's a matter of our recreation, just to have a break." Hence,recreation is a cause of social media usage without gender differences affecting it.

\section{B. ProfessionalLife}

This study identifiesprofessional life as the next theme,incorporated into four different codes.Five participants use social media for their professional lives, making professional reasons the second important reason to use social media. Males use social media to maintain their professional contacts because a male participant mentions that "LinkedIn help us to be connected with the professionals."However, females supportemployers' use of social media for their business, because a female participant mentions that "If you're looking to hire someone you might even look at their LinkedIn and their Facebook." Nevertheless, both genders usesocial media to increase their work opportunities and promote themselves as professionals, because it is mentioned by 4 participants.A participant mentions that "Yeah so the trigger would be work",and another participant mentions that "I think it's the same idea I would say like yeah I'm a very good boy professional on LinkedIn.” Thus, professional reasonsareother reasons to use social media without gender differences affecting it.

\section{Sharing}

This study identifies sharing as its next theme,showing the content types that males and females share. Sharing is incorporated into three different codes.Four participants use social media to share different materials, making sharing the secondlowest cause of social media usage. Both genders use social media to share pleasurable things because a male participant mentions that "That's very typical probably us Asians but that's what I do and all my friends do when they eat something nice, they share it on their Facebook", and a female participant mentions that "When eating something very, very delicious I will share them with my friends." However, males use social media to share news and their interest in different universities, because it is mentioned by two participants. A male participant mentions that "You find a video, you find it in CNN you put it there and then people start commenting on and that new videos come up", and another male participant mentions that "For example when I used to apply to different universities for admission, I got lots back with different faculties or different universities so I could see their interest, their recent works and share my interest."Hence, males are more likely to share the news. Therefore, gender differences influence the way social media relatesto different people's news consumption level.

\section{LeadersorFollowers}

This study identifies leaders or followers as the next theme, incorporated into three different codes. Six participants consider themselves as either leaders or followers in their social media usage, making this theme the most acknowledged theme. Both genders wish to initiate a discussion on Facebook. For example, a male participant mentions that "So normally like in terms of being initiated probably what I go and read about a news article or something so I might upload the video about the crash that recently happened." However, they dislike initiating a discussion on LinkedIn. For example, a female participantmentions that "It's usually because someone has contacted me...or whatever...or they've endorsed me or whatever and I've gone one and had a look." Nevertheless, some males dislikeinitiating a discussion on Facebook because it is mentioned by two male participants. A male participant mentions that "But I don't like information...just to measure dislikes things on Facebook because sometimes I need to check with all the customer feedback anytime and anywhere." Thus, females are more likely to initiate a discussion on social media. Consequently, gender differences can influence different people's initiatives to use social media.

\section{E. Competition}

This study identifies competition as the next theme, incorporated into three different codes. Social media challenge three participants, making competition the least important cause of social media usage along with personal life. Social media challenge both genders regarding their physical fitness because a male participant mentions that "Yeah I mean if I see a six-pack on a guy I start working out right away after", and a female participant mentions that "Well personally it challenges me to do other things, so for example if I've seen a friend of mine who was with me in the school has now run $10 \mathrm{~km}$ I'm like seriously if I can't run $10 \mathrm{~km}$ by the end of this month there's something wrong with me."Social media do not challenge some males, becauseit ismentioned by a male participant. The male participant mentions that "I don't feel competitive actually. They are doing well; I don't have a 


\section{Gender Differences in the Use of Social Media: Australian Postgraduate Students' Evidence}

problem with that."However, social mediachallengefemales to trek to nice places,because it is mentioned by a female participant. The female participant mentions that "You know you see people trekking nice places and you're like oh I could go there, that's a nice thing to do." Therefore, social media are more likely to challenge females. Thus, gender differences affect how people are challenged by different social media. Figure 1 depicts the conceptual model of this study.

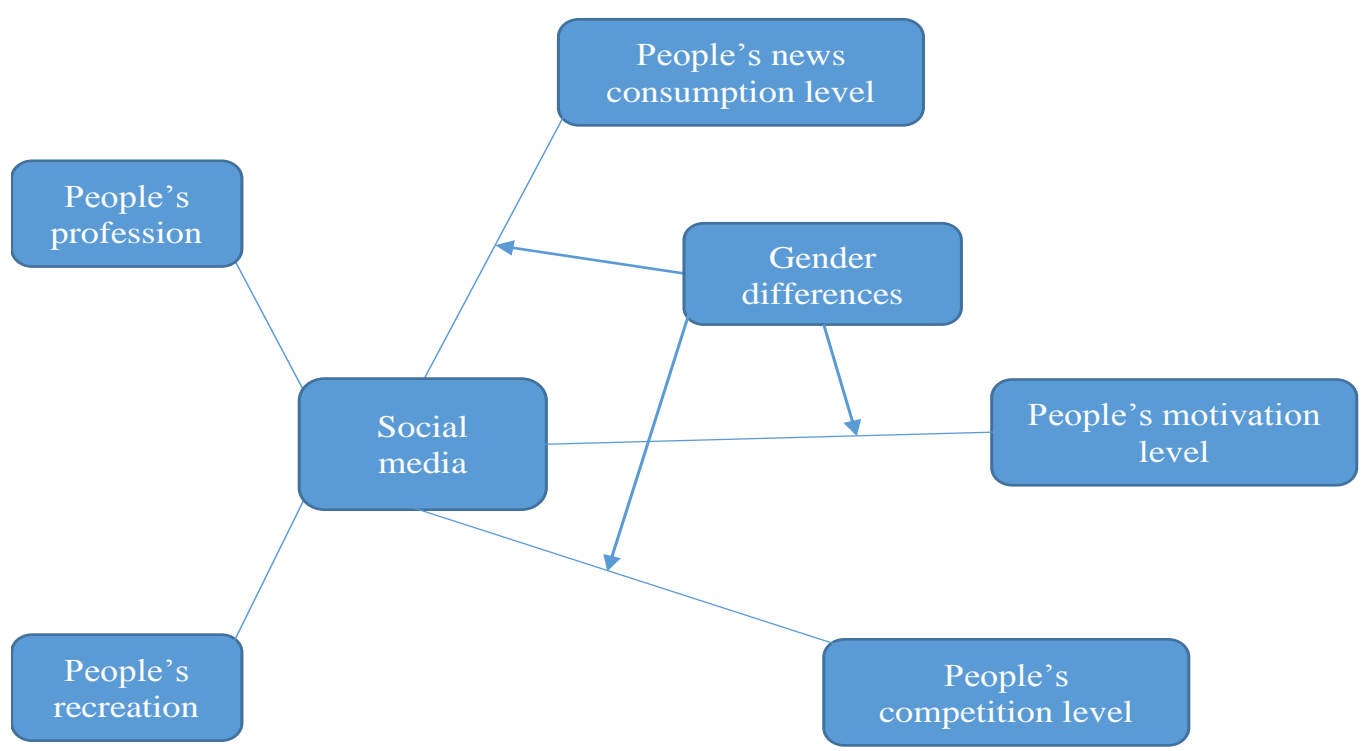

Figure 1.Conceptual Model of this Study

\section{CONCLUSION}

Social media can be defined as "applications, services, and systems that allow users to create, remix, and share content." (Junco, 2014 , p. 6) ${ }^{[80]}$. Social media usage is "the multiplicity of activities individuals may participate in online" (Smith and Gallicano, 2015 , p. 83) ${ }^{[81]}$. People use different social media platforms to discuss their opinions, share news, and connect with other people (Hung, Li, 2011) ${ }^{[82]}$.Social media affects different aspects of students' life. For example, social media is used to share information and academic interests among students, engage students, obtain a better understanding regarding students' activities, create study groups, improve e-textbooks by using them as a teaching tool, increase students' desire to learn the required courses, facilitate communication among students and working professionals, and help to conduct research(Lau, Lui, 2017) ${ }^{[83,}$ Cox and McLeod, 2014) ${ }^{[84]}$. Some universities use different social media platforms such as Twitter or Facebook to improve their teaching performance (Lau, 2017) ${ }^{[85]}$.

This study investigated the differences in male and female usage of social media in Australia. It was motivated by prior research failure to analyze male and female differences in their use of social media among Australian postgraduate students. The sample consisted of ten postgraduate students at the Queensland University of Technology who use social media platforms, including six males and four females. Nine themes and 41 codes were identified. This study analyzed five major themes, namely, personal life, professional life, sharing, leaders or followers, and competition. Leaders or followers were acknowledged by six participants, whereas personal life and competition were acknowledged by three participants. This study contributes by shedding some light on social media usage among postgraduate students. It helps universities to choose among different social media platforms for their educational purposes for their postgraduate students. Further, it shows how males and females treat information on different platforms, facilitating universities' planning.

This study suggests that social media may relate to people's recreation(Wood, Guerry, 2013) ${ }^{[86]}$ and their profession(Greysen, Kind, 2010) ${ }^{[87]}$, without gender differences affecting them.Moreover, it shows that males are more likely to share news on social media, suggesting that gender differences may influence the way social media relate to people's news consumption level. It found that females are more likely to initiate a discussion on social media, suggesting that gender differences influence the way social media relate to people's motivation level.Findings show that social media are more likely to challenge females, suggesting that gender differences influence the way social media relate to people's competition level. However, this study isnot without limitations. For example, it is conducted in a particular university,questioning its generalizability. Future research can explore the factors that affect different genders' social media usage andempirically test the conceptual model of this study.

\section{REFERENCES}

1) Gould, M. (2013) The Social Media Gospel: Sharing the Good News in New Ways. LITURGICAL Press. 


\section{Gender Differences in the Use of Social Media: Australian Postgraduate Students' Evidence}

2) Kietzmann, J.H., et al. (2011) Social media? Get serious! Understanding the functional building blocks of social media.. Business Horizons. 54(3): 241-251.

3) Manzoor, S.A. and A. Khan. (2019) Social media shapes university students' knowledge and perception of environmental issues. International Journal of Multidisciplinary Research and Studies. 2(10): 17-28.

4) Almenara-Niebla, S. and C. Ascanio-Sánchez. (2020) Connected Sahrawi refugee diaspora in Spain: Gender, social media and digital transnational gossip. European Journal of Cultural Studies. 23(5): 768-783.

5) Statista.2014 Statistics and facts about Social Networks. Available from: http://www.statista.com/topics/1164/socialnetworks/.

6) Kwon, O. and Y. Wen. (2010) An empirical study of the factors affecting social network service use. Computers in Human Behavior. 26(2): 254-263.

7) Bamman, D., J. Eisenstein, and T. Schnoebelen. (2014) Gender identity and lexical variation in social media. Journal of Sociolinguistics. 18(2): 135-160.

8) Herring, S.C. and J.C. Paolillo. (2006) Gender and genre variation in weblogs. Journal of Sociolinguistics. 10(4): 439459.

9) Heylighen, F. and J.-M. Dewaele. (2002) Variation in the contextuality of language: An empirical measure. Foundations of Science. 7(3): 293-340.

10) Argamon, S., et al. (2003) Gender, genre, and writing style in formal written texts. Text \& Talk. 23(3): 321-346.

11) Rao, D., et al.(2010). Classifying latent user attributes in Twitter. in Proceedings of the 2nd international workshop on Search and mining user-generated contents. Toronto, ON: ACM.

12) Kiesling, S.F. (2004) Dude. American Speech. 79(3): 281-305.

13) Evers, C.W., et al. (2013) Young people, social media, social network sites and sexual health communication in Australia:" This is funny, you should watch it". International Journal of Communication. 7(1): 355 - 359.

14) Wright, C.L. and M. Rubin. (2017) "Get lucky!” Sexual content in music lyrics, videos and social media and sexual cognitions and risk among emerging adults in the USA and Australia. Sex Education. 17(1): 41-56.

15) Kaplan, A.M. and M. Haenlein. (2010) Users of the world, unite! The challenges and opportunities of Social Media. Business Horizons. 53(1): 59-68.

16) Anttiroiko, A.-V. and R. Savolainen. (2011) Towards library 2.0: The adoption of web 2.0 technologies in public libraries. Libri. 61(2): 87-99.

17) Paul, M.J. and M. Dredze.(2011). You are what you tweet: Analyzing twitter for public health. in Fifth international AAAI conference on weblogs and social media. Baltimore: Citeseer.

18) De Choudhury, M., S. Counts, and E. Horvitz.(2013). Predicting postpartum changes in emotion and behavior via social media. in Proceedings of the SIGCHI conference on human factors in computing systems. Paris.

19) Kosinski, M., D. Stillwell, and T. Graepel. (2013) Private traits and attributes are predictable from digital records of human behavior. National Acad Sciences. 110(15): 5802-5805.

20) Argamon, S., et al. (2009) Automatically profiling the author of an anonymous text. Communications of the ACM. 52(2): 119-123.

21) Jones, R., et al.(2007). "I know what you did last summer" query logs and user privacy. in Proceedings of the sixteenth ACM conference on Conference on information and knowledge management. Lisboa: CIKM.

22) Pal, S. and K. Misra. (2019) Effect of social media on learning resistance among university students. ZENITH International Journal of Multidisciplinary Research. 9(1): 194-200.

23) Gross, E.F. (2004) Adolescent Internet use: What we expect, what teens report. Journal of Applied Developmental Psychology. 25(6): 633-649.

24) Vasan, M. (2016) Netizens' attitude towards social networking sites - A factor analysis approach. International Journal of Multidisciplinary Research and Development. 3(3): 201-204.

25) Grieve, R., et al. (2013) Face-to-face or Facebook: Can social connectedness be derived online? Computers in Human Behavior. 29(3): 604-609.

26) Anderson, B., et al. (2012) Facebook psychology: Popular questions answered by research. Psychology of Popular Media Culture. 1(1): 23-37.

27) Boyd, D.M. and N.B. Ellison. (2007) Social network sites: Definition, history, and scholarship. Journal of Computermediated Communication. 13(1): 210-230.

28) Madge, C., et al. (2009) Facebook, social integration and informal learning at university: 'It is more for socialising and talking to friends about work than for actually doing work'. Learning, Media and Technology. 34(2): 141-155.

29) Karakayali, N. and A. Kilic. (2013) More network conscious than ever? Challenges, strategies, and analytic labor of users in the Facebook environment. Journal of Computer-Mediated Communication. 18(2): 175-193. 


\section{Gender Differences in the Use of Social Media: Australian Postgraduate Students' Evidence}

30) Back, M.D., et al. (2010) Facebook profiles reflect actual personality, not self-idealization. Psychological Science. 21(3): 372-374.

31) Matzler, K., et al. (2008) Personality traits and knowledge sharing. Journal of Economic Psychology. 29(3): 301-313.

32) Zheng, W., et al. (2016) Profile pictures on social media: Gender and regional differences. Computers in Human Behavior. 63: 891-898.

33) Kapidzic, S. and S.C. Herring. (2015) Race, gender, and self-presentation in teen profile photographs. New Media \& Society. 17(6): 958-976.

34) Seidman, G. and O.S. Miller. (2013) Effects of gender and physical attractiveness on visual attention to Facebook profiles. Cyberpsychology, Behavior, and Social Networking. 16(1): 20-24.

35) Yang, Q. and Z. Li. (2014) A picture is worth a thousand words: Chinese college students' self-presentation on social networking sites. Journal of Communications Media Studies. 6(1): 70-94.

36) Döring, N., A. Reif, and S. Poeschl. (2016) How gender-stereotypical are selfies? A content analysis and comparison with magazine adverts. Computers in Human Behavior. 55: 955-962.

37) Reed, P. (2013) Hashtags and retweets: Using Twitter to aid community, communication and casual (informal) learning. Research in Learning Technology. 21: 1-21.

38) Simoes, P. and J. Mota.(2010). Twitter: The Heart of your PLE. in The PLE Conference 2010.

39) Couros, A.(2010) Developing personal learning networks for open and social learning, in Emerging technologies in distance education Athabasca University: Athabasca, AB. p. 109-128.

40) Palmer, S. (2013) Characterisation of the use of Twitter by Australian universities. Journal of Higher Education Policy and Management. 35(4): 333-344.

41) Evans, C. (2014) Twitter for teaching: Can social media be used to enhance the process of learning? British Journal of Educational Technology. 45(5): 902-915.

42) Conole, G. and P. Alevizou. (2010) A literature review of the use of Web 2.0 tools in Higher Education. A report commissioned by the Higher Education Academy August 2010.

43) Fernández Sánchez, M.R., F.I. Revuelta Domínguez, and M.J. Sosa Díaz. (2012) Redes sociales y microblogging: Innovación didáctica en la formación superior. RELATEC. 11(1): 61-74.

44) McArthur, J.A. and K. Bostedo-Conway. (2012) Exploring the relationship between student-instructor interaction on Twitter and student perceptions of teacher behaviors. International Journal of Teaching and Learning in Higher Education. 24(3): 286-292.

45) Kwak, H., et al.(2010). What is Twitter, a social network or a news media? in Proceedings of the 19th international conference on World wide web. Raleigh, NC: International World Wide Web Conference Committee

46) Carpenter, J.P. and D.G. Krutka. (2014) How and why educators use Twitter: A survey of the field. Journal of Research on Technology in Education. 46(4): 414-434.

47) Badge, J., et al. (2012) Observing emerging student networks on a microblogging service. Journal of Online Learning and Teaching. 7(1): 90-98.

48) Rinaldo, S.B., S. Tapp, and D.A. Laverie. (2011) Learning by tweeting: Using Twitter as a pedagogical tool. Journal of Marketing Education. 33(2): 193-203.

49) Johnson, K.A. (2011) The effect of Twitter posts on students' perceptions of instructor credibility. Learning, Media and Technology. 36(1): 21-38.

50) Duggan, M., et al. (2015) Social media update 2014. Pew Research Center. 19: 1-2.

51) Kim, K.-S., S.-C.J. Sin, and E.Y. Yoo-Lee. (2014) Undergraduates' use of social media as information sources. College \& Research Libraries. 75(4): 442-457.

52) Špiranec, S. and M.B. Zorica. (2010) Information Literacy 2.0: Hype or discourse refinement? Journal of Documentation. 66(1): 140-153.

53) Witek, D. and T. Grettano. (2012) Information literacy on Facebook: An analysis. Reference Services Review. 40(2): 242-257.

54) Chen, X., et al. (2015) Why students share misinformation on social media: Motivation, gender, and study-level differences. The Journal of Academic Librarianship. 41(5): 583-592.

55) Connaway, L.S., T.J. Dickey, and M.L. Radford. (2011) "If it is too inconvenient I'm not going after it:" Convenience as a critical factor in information-seeking behaviors. Library \& Information science research. 33(3): 179-190.

56) Lim, S. and C. Simon. (2011) Credibility judgment and verification behavior of college students concerning Wikipedia. First Monday. 16(4): 1-26.

57) Marengoni, A., et al. (2011) Aging with multimorbidity: A systematic review of the literature. Ageing Research Reviews. 10(4): 430-439. 


\section{Gender Differences in the Use of Social Media: Australian Postgraduate Students' Evidence}

58) Su, R., J. Rounds, and P.I. Armstrong. (2009) Men and things, women and people: A meta-analysis of sex differences in interests. Psychological Bulletin. 135(6): 859-884.

59) Huffaker, D.A. and S.L. Calvert. (2005) Gender, identity, and language use in teenage blogs. Journal of Computermediated Communication. 10(2): JCMC10211.

60) Sap, M., et al.(2014) Developing age and gender predictive lexica over social media. in Proceedings of the 2014 Conference on Empirical Methods in Natural Language Processing (EMNLP). Doha: Association for Computational Linguistics.

61) Mislove, A., et al. (2011) Understanding the demographics of Twitter users. ICWSM. 11(5): 25-29.

62) Goswami, S., S. Sarkar, and M. Rustagi.(2009). Stylometric analysis of bloggers' age and gender. in Third international AAAI conference on weblogs and social media. San Jose, CA.

63) Liu, W. and D. Ruths.(2013). What's in a name? using first names as features for gender inference in twitter. in 2013 AAAI Spring Symposium Series. Stanford, CA: Citeseer.

64) Women, H.(2012) Social media by gender: Women dominate Pinterest, Twitter, men dominate Reddit, YouTube. The Huffington Post, June 21.

65) Haferkamp, N. and N.C. Krämer. (2011) Social comparison 2.0: Examining the effects of online profiles on socialnetworking sites. Cyberpsychology, Behavior, and Social Networking. 14(5): 309-314.

66) Starr, L.R. and J. Davila. (2008) Excessive reassurance seeking, depression, and interpersonal rejection: A meta-analytic review. Journal of Abnormal Psychology. 117(4): 762-775.

67) Lenhart, A., et al.(2007) Teens and social media. Pew internet and American life project, Pew Research Center: Washington, DC.

68) Rideout, V.J., U.G. Foehr, and D.F. Roberts.2010 Generation M 2: Media in the lives of 8-to 18-year-olds. Available from: https://files.eric.ed.gov/fulltext/ED527859.pdf.

69) Lenhart, A.2012 Teens \& online video. Pew Internet \& American Life Project; Available from: https://www.ris.org/uploadi/editor/1340202136PIP Teens_and online_video.pdf.

70) Herring, S.C. and S. Kapidzic. (2015) Teens, gender, and self-presentation in social media. International encyclopedia of social and behavioral sciences. 2: 1-16.

71) Barker, V. (2009) Older adolescents' motivations for social network site use: The influence of gender, group identity, and collective self-esteem. Cyberpsychology \& Behavior. 12(2): 209-213.

72) Peluchette, J. and K. Karl. (2008) Social networking profiles: An examination of student attitudes regarding use and appropriateness of content. CyberPsychology \& Behavior. 11(1): 95-97.

73) Hennink, M., I. Hutter, and A. Bailey. (2010) Qualitative Research Methods. SAGE Publications.

74) Tracy, S.J. (2012) Qualitative Research Methods: Collecting Evidence, Crafting Analysis, Communicating Impact. Wiley.

75) Powell, R.A. and H.M. Single. (1996) Focus groups. International journal for quality in health care. 8(5): 499-504.

76) Morgan, D.L. (1997) Focus Groups as Qualitative Research. SAGE Publications.

77) Krueger, R.A. and M.A. Casey. (2009) Focus Groups: A Practical Guide for Applied Research. SAGE Publications.

78) Pandit, N.R. (1996) The creation of theory: A recent application of the grounded theory method. The qualitative report. 2(4): 1-14.

79) Corbin, J. and A. Strauss. (2007) Basics of Qualitative Research: Techniques and Procedures for Developing Grounded Theory. SAGE Publications.

80) Junco, R. (2014) Engaging students through social media: Evidence-based practices for use in student affairs. San Francisco, CA: John Wiley \& Sons.

81) Smith, B.G. and T.D. Gallicano. (2015) Terms of engagement: Analyzing public engagement with organizations through social media. Computers in Human Behavior. 53: 82-90.

82) Hung, K., S.Y. Li, and D.K. Tse. (2011) Interpersonal trust and platform credibility in a Chinese multibrand online community. Journal of Advertising. 40(3): 99-112.

83) Lau, W.W., V. Lui, and S.K. Chu. (2017) The use of wikis in a science inquiry-based project in a primary school. Educational Technology Research and Development. 65(3): 533-553.

84) Cox, D. and S. McLeod. (2014) Social media strategies for school principals. NASSP Bulletin. 98(1): 5-25.

85) Lau, W.W. (2017) Effects of social media usage and social media multitasking on the academic performance of university students. Computers in Human Behavior. 68: 286-291.

86) Wood, S.A., et al. (2013) Using social media to quantify nature-based tourism and recreation. Sci. Rep. 3.

87) Greysen, S.R., T. Kind, and K.C. Chretien. (2010) Online professionalism and the mirror of social media. Journal of general internal medicine. 25(11): 1227-1229. 